\title{
The Mesoproterozoic in the Nordic countries
}

1 Geological Survey of Norway, 7491 Trondheim, Norway. E-mail: bernard.bingen@ngu.no

2 Geological Survey of Sweden, Box 670,75128 Uppsala, Sweden.E-mail:jenny.andersson@sgu.se

3 Department of Geology, GeoBiosphere Science Centre, Lund University, Sölvegatan 12, 22362 Lund, Sweden.E-mail: ulf.soderlund@geol.lu.se

4 Geological Survey of Sweden, Kiliansgatan 10, 22350 Lund, Sweden. E-mail: charlotte.moller@sgu.se

During the Mesoproterozoic, central Fennoscandia and Laurentia (Greenland) were characterized by a weakly extensional stress regime, as evident from episodic rapakivi granites, dolerite dykes, continental rift intrusives, sandstone basins and continental flood basalts. Along the southwestern active margin of Fennoscandia, the 1.64-1.52 Ga Gothian and 1.52-1.48 Ga Telemarkian accretionary events resulted in oceanwards continental growth. The 1.47-1.42 Ga HallandianDanopolonian event included high-grade metamorphism and granite magmatism in southern Fennoscandia. The pre-Sveconorwegian 1.34-1.14 Ga period is characterized by bimodal magmatism associated with sedimentation, possibly reflecting transcurrent tectonics. The Sveconorwegian orogeny involved polyphase imbrication of terranes between 1.14 and $0.97 \mathrm{Ga}$, as a result of a collision between Baltica and another major plate, followed by relaxation and post-collisional magmatism between 0.96 and $0.90 \mathrm{Ga}$. Recent geologic data support classical models restoring the Sveconorwegian belt directly to the east of the Grenville belt of Laurentia at $1.0 \mathrm{Ga}$. Fragments of Paleo- to Mesoproterozoic crust showing late Grenvillian-Sveconorwegian (1.00-0.92 Ga) magmatism and/or metamorphism are exposed in several tectonic levels in the Caledonides of Scandinavia, Svalbard and East Greenland, on both sides of the inferred Iapetus suture. Linking these fragments into a coherent late-Grenvillian tectonic model, however, require additional study.

\section{Principal Mesoproterozoic lithotectonic domains}

Fennoscandia (the Fennoscandian shield) represents the northwestern part of Baltica or the East European Craton. At the start of the Mesoproterozoic, it consisted of Archean core (Karelia and Murmansk cratons) surrounded by Paleoproterozoic Svecofennian domains (sensu lato) intruded by the Transcandinavian Igneous Belt (TIB, Figure 1). During the Mesoproterozoic, the centre of Fennoscandia hosted episodic continental magmatism. The Timanian margin in the northeastern was passive, while the southwestern margin was active and the location of substantial continental growth. A regional metamorphic event, the Hallandian or Danopolonian orogeny is recorded in the southern part of Fennoscandia. Greenland

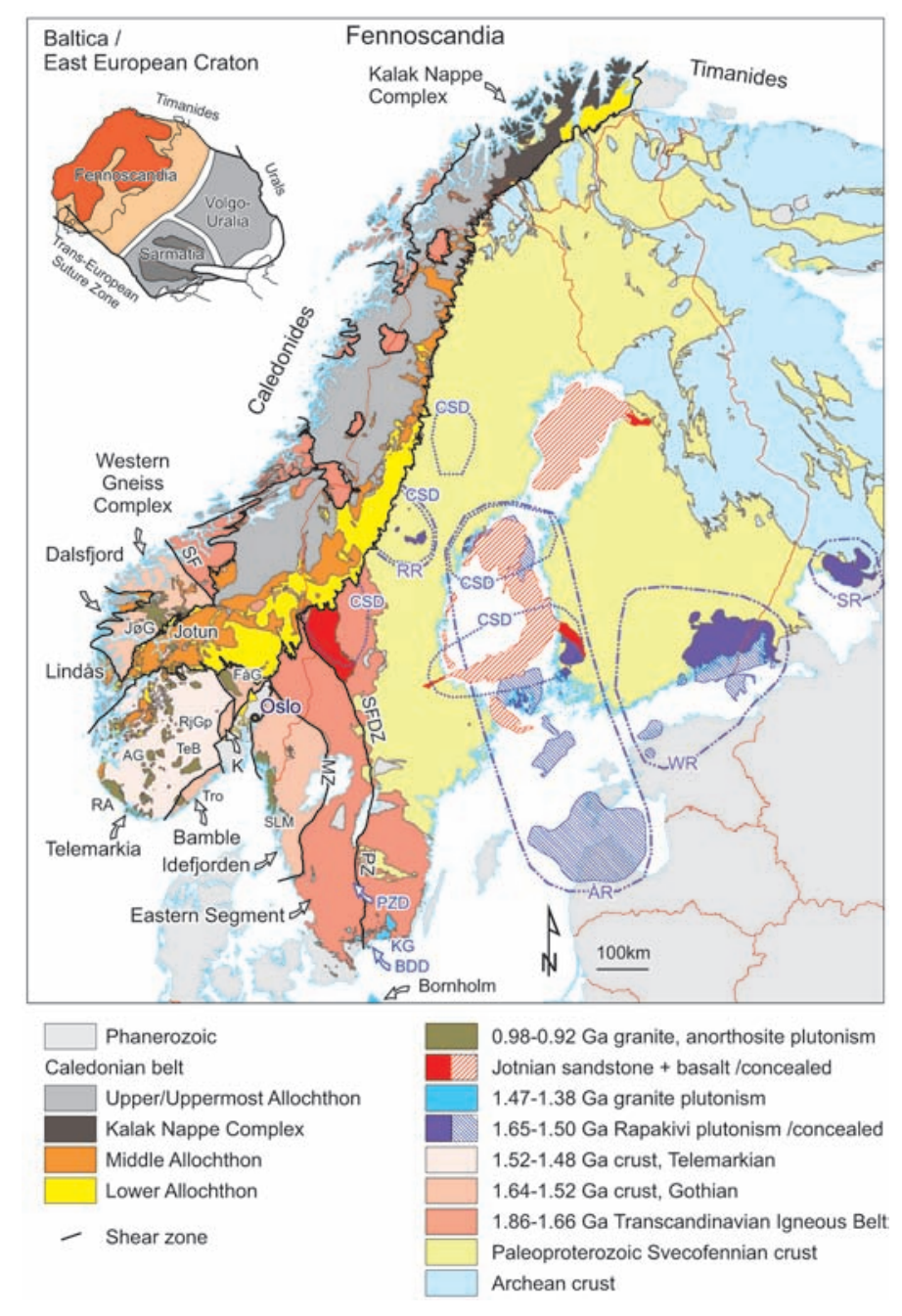

Figure 1 Sketch map of Fennoscandia in a Mesoproterozoic context. Abbreviations: AR: 1.59-1.56 Ga Aland rapakivi suite. AG: 0.97-0.95 Ga Agder post-collision granites; BDD: 0.98-0.95 Ga Blekinge-Dalarna dolerites; CSD: 1.27-1.25 Ga Central Scandinavian Dolerite Group; FåG: 0.93-0.92 Ga Flå, Bohus post-collision granites; JøG: 0.96-0.93 Ga Jøstler, Hafslo postcollision granite plutons; K: Kongsberg terrane; KG: 1.45 Ga Karlshamn granite; MZ: Mylonite Zone; PZ: Protogine zone; PZD: 1.22-1.20 Ga Protogine Zone dolerite and granites; RA: 0.93 Ga Rogaland anorthosite-mangerite-charnockite complex; RjGp: 1.51-1.50 Ga Rjukan group bimodal volcanic rocks; RR: 1.53-1.50 Ga Ragunda rapakivi suite; SFDZ: Sveconorwegian Frontal Deformation Zone; SF: Sveconorwegian Front in Western Gneiss Complex; SLM: 1.57 Ga Stora Le-Marstrand formation; SR: 1.55-1.53 Ga Salmi rapakivi suite; TeB: 1.28-1.14 Ga Telemarkia bimodal magmatism; Tro: 1.20-1.18 Ga Tromøy gabbro-tonalite complex, Bamble; WR: 1.65-1.61 Ga Wiborg rapakivi suite. 
was part of Laurentia. It is mainly made up of an Archean to Paleoproterozoic craton and contains only a minor Mesoproterozoic component.

At the end of the Mesoproterozoic, the southwestern margin of Fennoscandia was reworked during the Sveconorwegian orogeny, producing the c. $500 \mathrm{~km}$ wide Sveconorwegian orogenic belt (Figure 1). This belt is made up of five principal lithotectonic domains/segments, separated by Sveconorwegian crustal-scale shear zones. The easternmost domain, the Eastern Segment, exposes reworked lithologies of the TIB. West of the Mylonite Zone, a major Sveconorwegian lithotectonic terrane boundary, the Idefjorden, Kongsberg, Bamble and Telemarkia terranes are allochthonous and mainly the product of Mesoproterozoic continental growth (Bingen et al., 2005). Though most available evidence supports that they were marginal or attached to Fennoscandia during the Mesoproterozoic, models involving terrane accretion during the Sveconorwegian orogeny are plausible.

Late Grenvillian-Sveconorwegian overprint is detected in several units at different tectonostratigraphic levels in the Paleozoic Caledonides of East Greenland, Svalbard and Scandianavia (Figures $1,2,3)$. These rocks carry an important testimony for the understanding of the Mesoproterozoic, but are difficult to read, due to uncertainties in the Caledonian history.

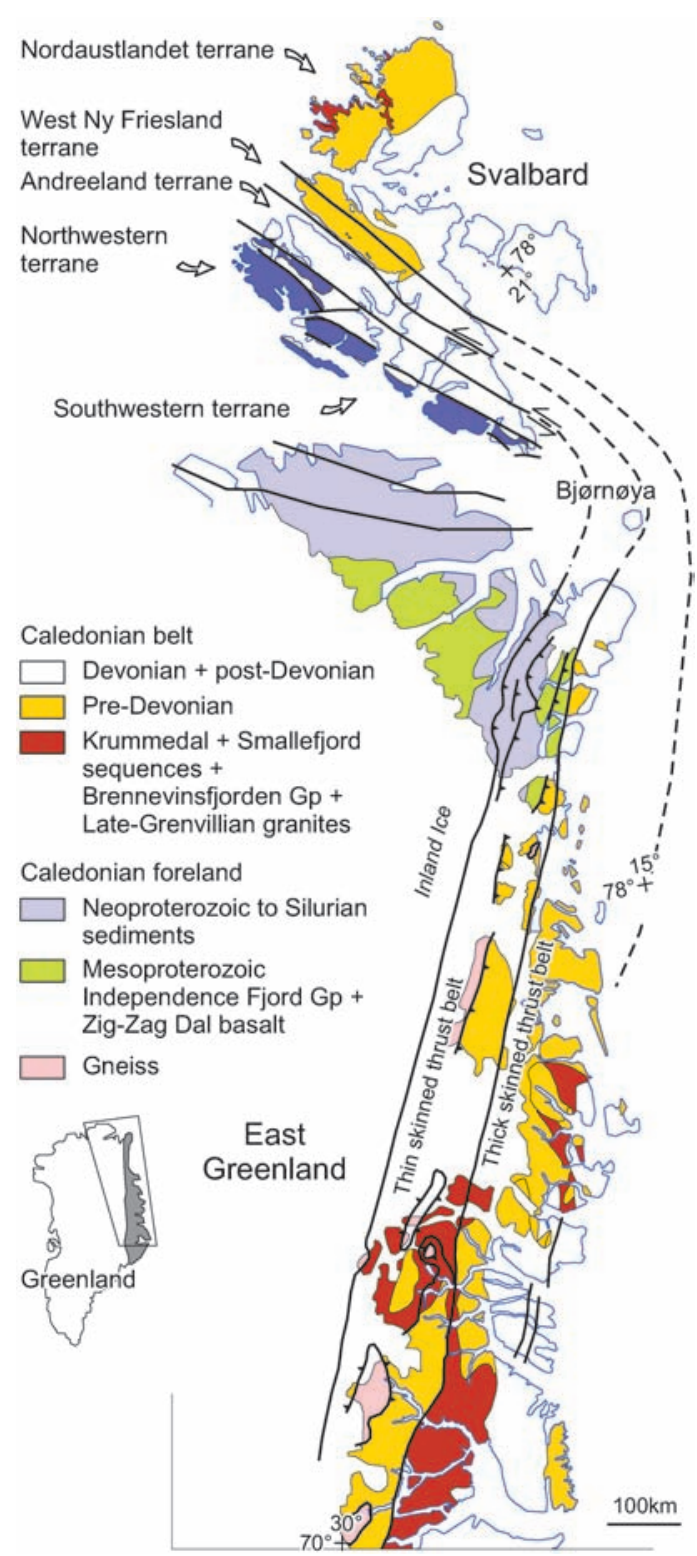

Figure 2 Sketch map of the Caledonian margin of Laurentia. Svalbard is reconstructed following Gee and Teben'kov (2004).

\section{Mesoproterozoic events in Fennoscandia}

\subsection{5-1.50 Ga Rapakivi magmatism}

Granite with a rapakivi texture, i.e. plagioclase mantling Kfeldspar phenocrysts, are diagnostic of a number of shallow, nonfoliated, dominantly felsic, plutons/batholiths intruded in central Fennoscandia (Figure 1; Haapala et al., 2005). Four rapakivi suites are distinct in time and space: from east to west, (1) the $1.55-1.53 \mathrm{Ga}$ Salmi suite, (2) 1.65-1.61 Ga Wiborg suite, (3) 1.59-1.56 Ga Åland suite, and (4) 1.53-1.50 Ga comparatively small plutons of the Ragunda suite in central Sweden. Rapakivi plutonism overlaps in time with intrusion of dolerite dykes and sills in Sweden and Finland and a large anorthosite complex, the 1.53-1.50 Ga Mazury complex in Poland. The rapakivi granites and related magmatism reflects an intracontinental extensional setting.

\subsection{4-1.52 Ga Gothian accretion}

The Idefjorden terrane, and parts of the Bamble and Kongsberg terranes, west of the Mylonite zone (Figure 1), are made up of 1.64-1.52 Ga plutonic, volcanic and sedimentary rocks. The magmatic rocks have a juvenile calc-alkaline geochemical signature typical for an active margin setting. Some tholeiitic mafic metavolcanic rocks with oceanic volcanic arc signature and some metasediments showing a restricted zircon provenance pattern suggest that at least part of the island arc sequence formed off-board of a Paleoproterozoic continent.

The Gothian event relates to the 1.64-1.52 Ga geological evolution in the Idefjorden terrane (Figure 4) and can be classified as an accretionary event. The lithologies exposed in the Idefjorden terrane can be interpreted in the context of a single, progressively maturing, volcanic arc, variably-distal to Fennoscandia (Andersen et al., 2004), or as several volcanic arcs accreted shortly after formation. Due to Sveconorwegian overprint, structures related to the Gothian event prove difficult to trace at any large scale. Gothian amphibolite-facies structures are locally observed, but robust age constraints on Gothian metamorphism are lacking.

\subsection{2-1.48 Ga Telemarkian accretion}

The southwesternmost Sveconorwegian terrane, the Telemarkia terrane (Figure 1), can be divided into four sub-domains, the Telemark, Hardangervidda, Suldal and Rogaland-Vest Agder sectors. These sectors show distinct lithologies and metamorphic overprint, but share a common record of voluminous $1.52-1.48 \mathrm{Ga}$ magmatism. This continental building event is here referred to as the Telemarkian (Figure 4). The geochemistry of the 1.52-1.48 Ga magmatic suites is poorly characterized, except for the Rjukan Group bimodal volcanics in Telemark, which show a continental rift signature. The magmatic rocks are overlain by quartzites, containing abundant Paleoproterozoic and Archean clastic material. This implies proximity of an evolved continent. Formation of the Telemarkia terrane at $1.52-1.48 \mathrm{Ga}$ is probably best interpreted in the context of a continental arc.

\subsection{7-1.42 Ga Hallandian and Danopolonian orogenies}

In central Fennoscandia, rapakivi intrusives are unconformably overlain by an up to $800 \mathrm{~m}$ thick, cover of continental sandstone, the Jotnian sandstones (Figure 1). These are preserved in undeformed basins and interlayered with a c. $100 \mathrm{~m}$ thick tholeiitic basalt, showing geochemical similarity with rift-related or continental flood basalt. Some 1.46 Ga dolerites may represent feeder to the basalts.

Contrasting with the extensional regime in central Fennoscandia, the south-southwestern margin (southern Sweden, Bornholm and the concealed basement of Lithuania and Poland) was the loca- 


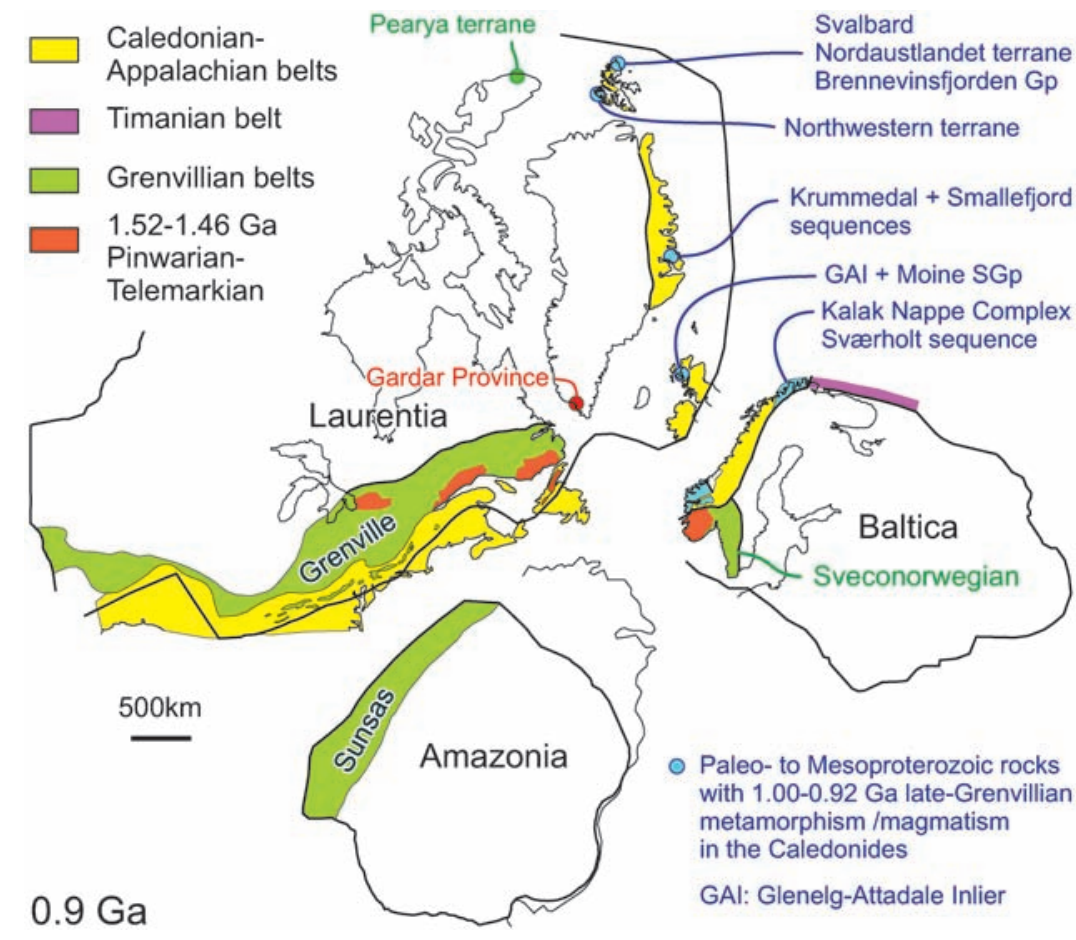

Figure 3 Classical Baltica-Laurentia-Amazonia paleogeographic reconstruction at the end of the Mesoproterozoic, following Cawood et al. (2007).

tion of volumetrically limited but widespread granite magmatism between 1.46 and $1.44 \mathrm{Ga}$, as well as an orogenic event, referred to as the Hallandian or Danopolonian orogeny (Figures 1,4). The Hallandian is defined in the Eastern Segment of the Sveconorwegian belt and its eastern boundary, the Protogine zone. It is characterized by $1.46-1.42 \mathrm{Ga}$ amphibolite-facies metamorphism, associated with regional scale migmatitization and locally gneissic layering (Möller et al., 2007). The Danopolonian is defined outside of the Sveconorwegian belt. Evidence for Danopolonian deformation includes syn-intrusion deformation in $1.45 \mathrm{Ga}$ plutons in southern Fennoscandia and $1.49-1.45 \mathrm{Ga}{ }^{40} \mathrm{Ar} /{ }^{39} \mathrm{Ar}$ hornblende ages from drill cores in Lithuania possibly related to large E-W trending shear zones. The relation between the Hallandian and Danopolonian events and the significance of the Hallandian-Danopolonian as a large scale orogenic event are difficult to assess today. It may be related to a collision, reworking the south-southwestern margin of Fennoscandia, or to a change in subduction geometry in an active margin setting.

\subsection{4-1.14 Ga Pre-Sveconorwegian interval}

In central Fennoscandia, the extensive Central Scandinavian Dolerite Group formed around five magmatic complexes, formed in three distinct pulses between 1.27 and 1.25 Ga (Figure 1). It may record hotspot activity or back-arc extensional setting (Söderlund et al., 2006).

The allochthonous Sveconorwegian terranes are characterized by abundant pre-Sveconorwegian 1.34-1.14 Ga bimodal magmatism, variably interlayered with clastic sediments showing rapid lateral variation and local unconformities. The Bamble terrane hosts the $1.20-1.18 \mathrm{Ga}$ Trom $\varnothing y$ gabbro-tonalite complex (Figure 1). The geotectonic setting prevailing in the Sveconorwegian terranes before the Sveconorwegian orogeny is controversial. The tholeiitic Tromøy complex is interpreted as the remnants of an immature island arc accreted at an early stage of the Sveconorwegian orogeny. Bimodal magmatic suites asso- ciated with sedimentary basins can be interpreted in the context of an extensional or transtensional regime located in a continental arc, continental back-arc or Basin and Range environment. Large scale transcurrent movements of the Sveconorwegian terranes probably took place before and during the Sveconorwegian orogeny. This is compatible with the lack of evidence for Hallandian or Danopolonian overprint in these terranes.

\subsection{4-0.90 Ga Sveconorwegian orogeny}

Sveconorwegian high-grade metamorphism is dated between 1.14 and $0.90 \mathrm{Ga}$, defining the total duration of this orogeny. The Sveconorwegian orogeny is interpreted as a polyphase imbrication of terranes at the margin of Fennoscandia between 1.14 and $0.97 \mathrm{Ga}$, as a result of a continent-continent collision. Collision was followed by relaxation between 0.96 and $0.90 \mathrm{Ga}$. Syn- and post-collision magmatism increases dramatically towards the west.

Early-Sveconorwegian 1.14-1.08 Ga amphiboliteto granulite-facies metamorphism is observed in the Bamble and Kongsberg terranes (Arendal phase; Figure 4). These terranes form two tectonic wedges between the Idefjorden and Telemarkia terranes. The 1.14-1.08 Ga metamorphism may record early-Sveconorwegian collision between the Idefjorden and Telemarkia terranes, possibly involving accretion of the Tromøy arc. At 1.05 $\mathrm{Ga}$, crustal thickening and deformation propagated towards the Idefjorden and Telemarkia terranes (Agder phase; Figure 4). The Idefjorden terrane is characterized by $1.05-1.02 \mathrm{Ga}$ greenschist to amphibolite facies metamorphism, locally reaching high-pressure granulite-facies conditions and by several orogen-parallel shear zones interpreted as oblique thrusts. In the Telemarkia terrane, $1.05 \mathrm{Ga}$ syn-collision crustal melting was followed by regional metamorphism between 1.03 and $0.97 \mathrm{Ga}$, peaking in granulite-facies conditions in the Rogaland-Vest Agder
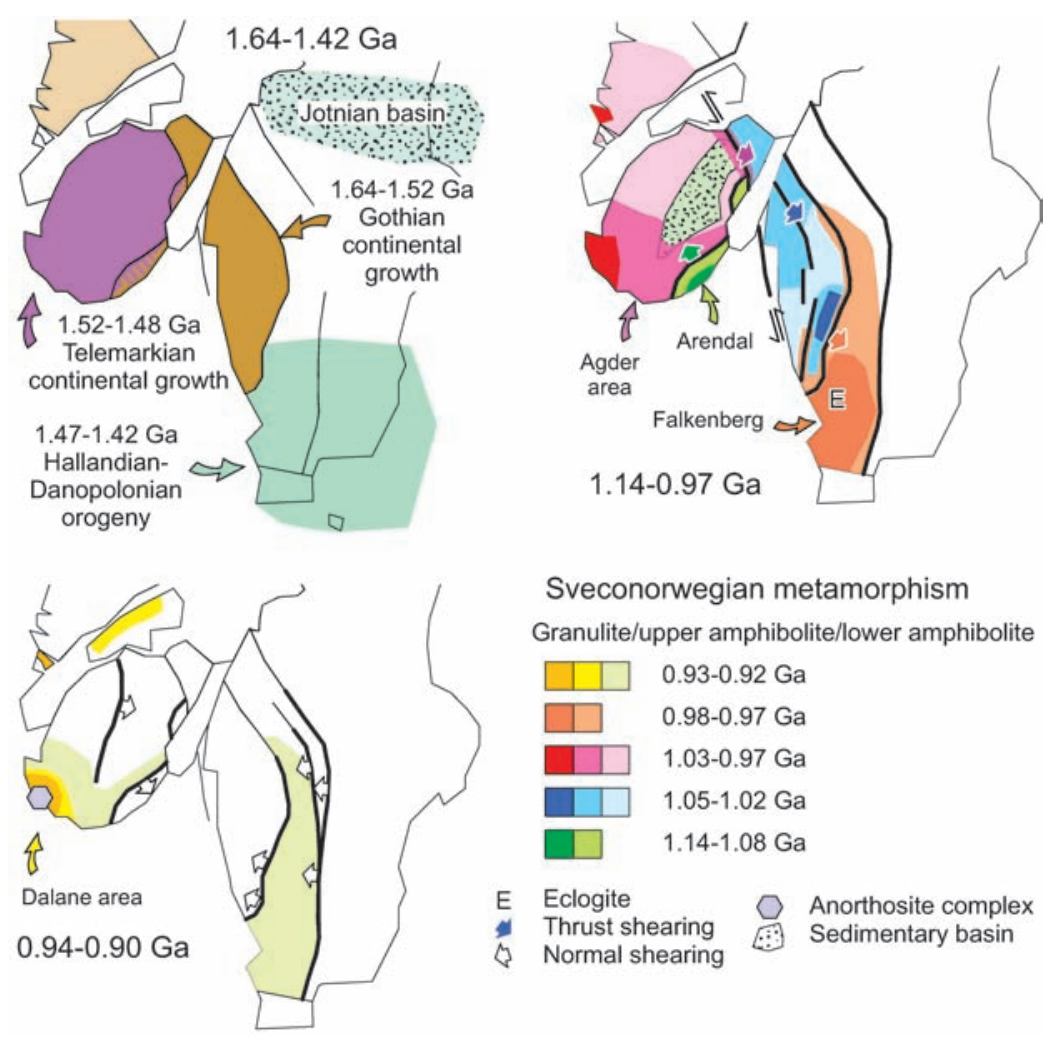

Sveconorwegian metamorphism

Granulite/upper amphibolite/lower amphibolite

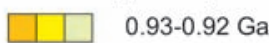

$0.98-0.97 \mathrm{Ga}$

1.03-0.97 Ga

$1.05-1.02 \mathrm{Ga}$

$1.14-1.08 \mathrm{Ga}$

E Eclogite

Thrust shearing

Normal shearing

Anorthosite complex Sedimentary basin

Figure 4 Schematic distribution of orogenic and metamorphic events affecting the southwestern margin of Fennoscandia during the Mesoproterozoic. 
sector (Figures 4, 5). At $0.98 \mathrm{Ga}$, the orogeny propagated further towards the east to include the Eastern Segment (Falkenberg phase; Figure 4). In the core of the high-grade domain, high-pressure granulites and retrogressed eclogites attest to burial of large parts of the Eastern Segment to a depth of at least $35 \mathrm{~km}$ at $0.97 \mathrm{Ga}$, with simultaneous tectonic emplacement of an even deeper eclogite-bearing unit. Eclogite formation was shortly followed by exhumation.

After $0.97 \mathrm{Ga}$, the Sveconorwegian belt progressively collapsed probably in a dominantly extension regime (Dalane phase, Figure 4). The 0.98-0.95 Ga Blekinge-Dalarna dolerites intruded the foreland of the belt (Figure 1; Söderlund et al., 2005). The Eastern Segment is characterized by prominent folds reflecting crustal flow associated with exhumation of the high-pressure rocks (Möller et al., 2007). In the Rogaland-Vest Agder sector, Telemarkia terrane, $0.97-0.95 \mathrm{Ga}$ post-collision granite magmatism is associated with regional decompression. A final voluminous pulse of plutonism, at 0.93-0.92 Ga, includes the Rogaland anorthosite complex (Figure 1) and spatially related high temperature-low pressure metamorphism. The Rogaland-Vest Agder sector can be interpreted as a large scale gneiss dome formed between 0.97 and $0.92 \mathrm{Ga}$, bringing hot ductile crust and plutonism to a shallow level (2-4 kbar) (Bingen et al., 2006).

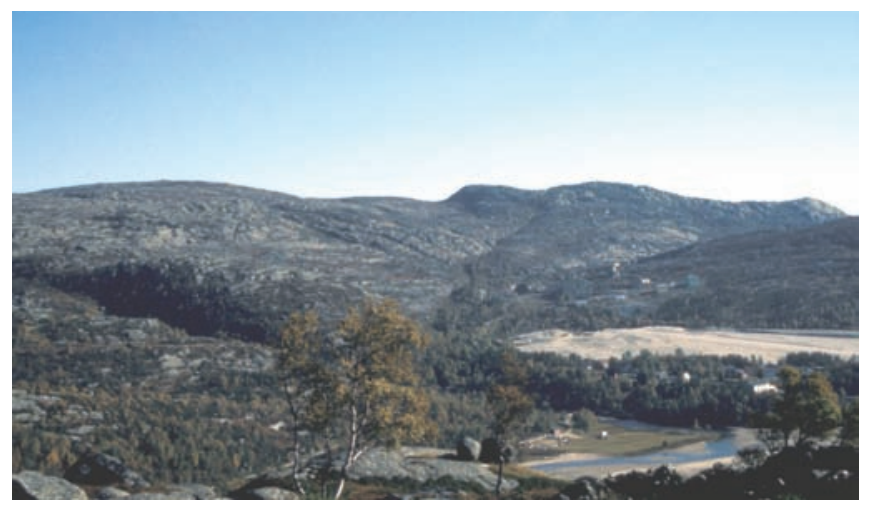

Figure 5 Overview of the Knaben Mo-district in southern Norway, mined up to 1973. Widespread syn-collision granite magmatism took place during the Sveconorwegian orogeny in the Telemarkia terrane. In Knaben, intrusion of a 1.02 Ga granite plug is associated with deposition of molybdenite.

\section{Mesoproterozoic events in Greenland (Laurentia)}

\subsection{Ga Zig-Zag Dal basalt magmatism}

In North Greenland, Paleo- to Mesoproterozoic sandstones of the Independence Fjord Group overly a concealed crystalline basement (Figure 2). The sandstone sequence hosts numerous $1.38 \mathrm{Ga}$ mafic intrusions known as the Midsommers $\emptyset$ dolerites. The sandstone sequence is conformably overlain by an up to $1350 \mathrm{~m}$ thick tholeiitic flood basalt, the Zig-Zag Dal basalt. This basalt probably results from ascent of a mantle plume (Upton et al., 2005).

\subsection{8-1.14 Ga Gardar province}

The Gardar Province occupies a ENE trending rift structure in the Paleoproterozoic Ketilidian orogen of South Greenland (Figure 3 ). It consists of alkaline $1.28-1.14 \mathrm{Ga}$ mafic dykes, syenite to nepheline syenite plutons and minor lamprophyre and carbonatite intrusions. The plutons are associated with a fault-bounded sediment and volcanic basin. An older $1.35 \mathrm{Ga}$ intrusive phase is possible. The Gardar province is part of widespread evidence for Mesoproterozoic intracontinental extension in Laurentia.

\section{Mesoproterozoic rocks in the Caledonides}

\section{East Greenland}

In East Greenland, the Caledonides divide into two allochthonous belts (thin and thick skinned) transported westwards onto the Laurentia basement (Figure 2; Higgins et al., 2004). Each of them is made of several nappes, and both of them are regarded as endemic to Laurentia before the Caledonian orogeny. Psammitic paragneisses of the Krummedal and Smallefjord sequences are exposed in both allochthonous belts. They were deposited after c. $1.00 \mathrm{Ga}$ and contain abundant Mesoproterozoic detrital zircons. They are affected by a $0.95 \mathrm{Ga}$ late-Grenvillian medium to high-grade metamorphism, intruded by $0.94-0.92$ Ga granitoids and overlain by a thick Neoproterozoic shallow-marine sequence (the Eleonore Bay Supergroup).

\section{Svalbard}

Svalbard is reconstructed north of Greenland before the Cenozoic opening of the North Atlantic. Following Gee and Teben'kov (2004), the Svalbard Caledonides represent the direct along strike extension of the East Greenland Caledonides (Figure 2). Svalbard's pre-Devonian bedrock divides into five terranes, from east to west, the Nordaustlanded, West Ny Friesland, Andréeland, Northwestern and Southwestern terranes.

In the Nordaustlandet terrane, the lowermost exposed stratigraphic unit is the metasedimentary Brennevinsforden group, deposited after $1.05 \mathrm{Ga}$, on top of an unknown basement. It is intruded by $0.96-0.93 \mathrm{Ga}$ granites and overlain by $0.96 \mathrm{Ga}$ rhyolites. The rhyolites are unconformably overlain by the Neoproterozoic Murchisonfjorden supergroup. The Brennevinsforden group correlates well with the Krummedal-Smallefjord sequence in East Greenland.

The Western Ny Friesland terrane consists of a Paleoproterozoic basement overlain by Mesoproterozoic quartzite hosting ca. 1.3 Ga dykes. It lacks Grenvillian overprint. The Northwestern and Southwestern terranes in Spitsbergen show a poorly characterized Mesoproterozoic basement intruded by 0.96 Ga granites. These terranes have affinity with the Pearya terrane exposed on Ellesmere Island, Arctic Canada.

\section{Scandinavian Caledonides}

The Scandinavian Caledonides (Figure 1) consist of four levels of thrust sheets, transported eastwards onto the Fennoscandia platform. They are referred to as the Lower, Middle, Upper and Uppermost Allochthons. The Lower and Middle Allochthons are generally considered endemic to Fennoscandia before the Caledonian orogeny. The lower part of the Upper Allochthon has a disputed origin (endemic vs. exotic), while the upper part of the Upper Allochthon and the Uppermost Allochthon are regarded as exotic terrains with an Iapetus Ocean or Laurentian ancestry.

The Western Gneiss Complex (Figure 1) is a large basement window in western Norway, interpreted as Fennoscandia Paleoproterozoic crust below the Caledonian nappes. The southern part of the Western Gneiss Complex is affected by a 0.99-0.95 Ga Sveconorwegian metamorphic overprint and 0.96-0.93 Ga granite magmatism (Figures 1, 3, 4). The front of Sveconorwegian reworking in the Western Gneiss Complex (SF in Figure 1) is approximately aligned with the Sveconorwegian Frontal Deformation Zone southeast of the Caledonian nappe front (SFDZ in Figure 1). Consequently the Western Gneiss Complex is commonly correlated with the Eastern Segment. In detail, this correlation nevertheless suffers from a number of shortcomings.

The crystalline Lindås, Dalsfjord and Jotun Nappes are located in the Middle Allochthon in western Norway (Figures 1,3). They are made up of Paleo- to Mesoproterozoic crystalline rocks. They show 
late-Sveconorwegian $0.95-0.92 \mathrm{Ga}$ metamorphism and $0.95 \mathrm{Ga}$ anorthosite magmatism (Figure 4; Lundmark et al., 2007).

The Kalak and Seve Nappe Complexes are attributed to the lower part of the Upper Allochthon (Figure 1). The lower metasesediment sequence in the Kalak nappes, the Sværholt sequence, was deposited after $1.03 \mathrm{Ga}$ and intruded by $0.98-0.97 \mathrm{Ga}$ granite after a deformation phase (Kirkland et al., 2007). Metasediments of the Kalak and Seve nappes contains abundant populations of Grenvillian and older Mesoproterozoic detrital zircons. The Kalak and Seve Nappe Complexes are generally interpreted as part of the Neoproterozoic passive margin of Fennoscandia during opening of Iapetus. Recent data, nevertheless, underscore the similarities between the Sværholt sequence in the Kalak Nappe Complex and the Krummedal-Smallefjord sequences and Brennevinsfjorden group in East Greenland and Svalbard (Figure 3). This rather suggests a common exotic origin for these three units.

\section{On the road to Rodinia?}

Classical paleogeographic models restore Baltica in a variety of configurations to the east of Laurentia for most of the Mesoproterozoic and Neoproterozoic (Figure 3). Large scale geotectonic interpretations picture a common long-lived active continental margin during the Mesoproterozoic for the two plates, facing the southeast for Laurentia and southwest for Baltica (Karlstrom et al., 2001; Cawood et al., 2007; Bogdanova et al., 2007). Periods of advancing subduction boundary, retreating subduction boundary or change in subduction geometry account for the diversity of tectonic regimes and rock assemblages along this margin. The summary presented in this paper shows that it is possible to interpret the Mesoproterozoic geology of Fennoscandia in this unifying model.

At the end of the Mesoproterozoic, the Grenville orogeny, sensu lato, involved collision of a number of continents at planetaryscale and allegedly resulted in assembly of the Rodinia supercontinent. The configuration of Rodinia is, however, speculative. Following classical models, the Laurentia-Baltica active margin collided with another major plate, presumably Amazonia, to form the Grenville belt, sensu stricto, in Laurentia, and the Sveconorwegian belt in Baltica. Formation of the Grenville-Sveconorwegian belt, extending from Texas to Sweden, by collision with the comparatively small Amazonia would, however, require large-scale transcurrent movement of Amazonia.

The classical Baltica-Laurentia-Amazonia reconstruction (Figure 3) for the Mesoproterozoic to Neoproterozoic is disturbing, as it features Baltica and Laurentia at almost exactly the same relative position at two occasions in the past, namely after the Grenvillian orogeny and after the Caledonian orogeny. Such a coincidence would imply a simple Wilson cycle between the two orogenies, a fact hardly compatible with the inferred large drift of Baltica during the Phanerozoic and with the complexity of the Caledonian orogenic belt. Nevertheless, as a matter of fact, recent geologic-geochronologic data support the link between the Grenville and Sveconorwegian belts, and thus support classical Neoproterozoic LaurentiaBaltica reconstruction. For example, (1) Voluminous 1.5 Ga plutonism, volcanism and clastic sediment basin formation are remarkably similar in the eastern Grenville province (the Pinwarian event) and the Telemarkia terrane (the Telemarkian event) (Figure 3). (2) The two belts and their foreland share a phase of continental, mainly mafic, magmatism, between 1.28 and $1.23 \mathrm{Ga}$ (Söderlund et al., 2006). (3) While early Grenvillian metamorphic phases are diachronous in the two belts (1.24-1.22 Elzevierian, 1.19-1.14 Ga Shawinigan and 1.14-1.08 Ga Arendal phases), the main Grenvillian convergence-related metamorphic phases overlap. These are the 1.08-1.02 Ga Ottawan and 1.01-0.98 Ga Rigolet phases in the Grenville belt overlapping with the $1.05-0.98 \mathrm{Ga}$ Arendal and 0.98-0.97 Ga Falkenberg phases in the Sveconorwegian belt. Especially significant is the coeval character of high-pressure 1.06-1.04 Ga metamorphism.

\section{Late-Grenvillian in the Caledonides}

Fragments of Paleo- to Mesoproterozoic crustal domains showing a late-Grenvillian metamorphic overprint and/or hosting late-Grenvillian intrusive rocks are detected along the whole length of the Caledonides, not only in the Nordic countries, as reviewed above, but also in Scotland (Glenelg-Attadale Inlier and Moine supergroup) (Figure 3). These fragments are situated on both sides of the main Caledonian (Scandian) suture zone, as defined by Iapetus related ophiolite complexes (Upper-Uppermost allochthons), and they are hosted in short- as well as far-travelled nappes. Two trends emerge though available data are sparse. (1) The timing of overprint in these fragments is typically in the interval between $1.00 \mathrm{Ga}$ and $0.92 \mathrm{Ga}$ and thus corresponds to the last increment of convergence and to the post-convergence relaxation in the Grenville and Sveconorwegian belts sensu stricto. (2) The Krummedal-Smallefjord sequences, Brennevinsfjorden group and the Sværholt sequence (Kalak Nappe Complex), represent accumulation of thick sediment packages in late-Mesoproterozoic basins, overlain by thick Neoproterozoic sediment sequences. These features contrast with the scarcity of lateMesoproterozoic to Neoproterozoic sediments in the Grenville and Sveconorwegian belts sensu stricto.

The different fragments of crust hosted in the Caledonides recording late-Grenvillian magmatism and/or metamorphism could be interpreted as the remnants of a coherent Grenvillian orogenic belt, branching northwards from the main Grenvillian-Sveconorwegian belt along the axis of the Caledonides (Figure 3). A northwards trending branch could result from final transpressional imbrication of Amazonia into Baltica, generating locally thick sediment sequences and magmatism. Nevertheless, several arguments prompt caution. The occurrence of late-Grenvillian rocks in Taimyr (Central Belt) and Ellesmere Islands (Pearya terrane) outside of the Caledonian belt may attest to an independent late-Grenvillian orogenic tract in the Arctic, possibly representing an alternative origin for these fragments. Also, the Kalak Nappe Complex shows evidence for Neoproterozoic magmatism and deformation, suggesting a possible link with the Timanian belt or peri-Gondwana terranes rather than the Grenville and Sveconorwegian belts sensu stricto. Further study of the Mesoproterozoic and Neoproterozoic sequences captured in the Caledonides and the relations between the Caledonian belt, Timanian belt and other orogenic belts in the Arctic is required to understand the significance of the late-Grenvillian record in the Caledonides.

\section{Acknowledgements}

A. Solli prepared the map of Figure 1. O. Bolle, J.S. Daly and D.G. Gee are thanked for reviewing the manuscript.

\section{References}

Andersen, T., Griffin, W.L., Jackson, S.E., Knudsen, T.-L. and Pearson, N.J. 2004, Mid-Proterozoic magmatic arc evolution at the southwest margin of the Baltic shield: Lithos, v. 73, pp. 289-318.

Bingen, B., Skår, Ø., Marker, M., Sigmond, E.M.O., Nordgulen, Ø., Ragnhildstveit, J., Mansfeld, J., Tucker, R.D. and Liégeois, J.-P., 2005, Timing of continental building in the Sveconorwegian orogen, SW Scandinavia: Norwegian Journal of Geology, v. 85, pp. 87-116.

Bingen, B., Stein, H.J., Bogaerts, M., Bolle, O. and Mansfeld, J., 2006, Molybdenite Re-Os dating constrains gravitational collapse of the Sveconorwegian orogen, SW Scandinavia: Lithos, v. 87, pp. 328-346.

Bogdanova, S., Bingen, B., Gorbatschev, R., Kheraskova, T., Kozlov, V., Puchkov, V. and Volozh, Y., 2007, The East European Craton (Baltica) before and during the assembly of Rodinia Precambrian Research, v.160, pp. 23-45.

Cawood, P.A., Nemchin, A.A., Strachan, R., Prave, T. and Krabbendam, M. 2007, Sedimentary basin and detrital zircon record along East Laurentia and Baltica during assembly and breakup of Rodinia: Journal of the Geological Society, London, v. 164, pp. 257-275. 
Gee, D.G. and Tebenkov, A.M., 2004, Svalbard: a fragment of the Laurentia margin: in Gee, D.G. and Pease, V., eds, The Neoproterozoic Timanide Orogen of Eastern Baltica, Geological Society, London, Memoirs, v. 30, pp. 191-206.

Haapala, I., Rämö, O.T. and Frindt, S., 2005, Comparison of Proterozoic and Phanerozoic rift-related basaltic-granitic magmatism: Lithos, v. 80, pp. $1-32$.

Higgins, A.K., Elvevold, S., Escher, J.C., Frederiksen, K.S., Gilloti, J.A., Henriksen, N., Jepsen, H.F., Jones, K.A., Kalsbeek, F., Kinny, P.D., Leslie, A.G., Smith, M.P., Thrane, K. and Watt, G.R., 2004, The foreland-propagating thrust architecture of the East Greenland Caledonides $72^{\circ}-75^{\circ} \mathrm{N}$ : Journal of the Geological Society, London, v. 161, pp. 1009-1026.

Karlstrom, K.E., Åhäll, K.-I., Harlan, S.S., Williams, M.L., McLelland, J. and Geissman, J.W., 2001, Long lived (1.8-1.0 Ga) convergent orogen in southern Laurentia, its extensions to Australia and Baltica, and implications for refining Rodinia: Precambrian Research, v. 111, pp. 5-30.

Kirkland, C.L., Daly, J.S. and Whitehouse, M.J., 2007, Provenance and terrane evolution of the Kalak Nappe Complex, Norwegian Caledonides: Implications for neoproterozoic paleogeography and tectonics: Journal of Geology, v. 115 , pp. $21-41$.

Lundmark, A.M., Corfu, F., Spürgin, S. and Selbekk, R., 2007, Proterozoic evolution and provenance of the high-grade Jotun Nappe Complex, SW Norway: U-Pb geochronology: Precambrian Research, v. 159, pp. 133-154.

Möller, C., Andersson, J., Lundqvist, I. and Hellström, F.A., 2007, Linking deformation, migmatite formation and zircon $\mathrm{U}-\mathrm{Pb}$ geochronology in polymetamorphic gneisses, Sveconorwegian province, Sweden: Journal of Metamorphic Geology, v. 25, pp. 727-750.

Söderlund, U., Isachsen, C.E., Bylund, G., Heaman, L.M., Patchett, P.J., Vervoort, J.D. and Andersson, U.B., 2005, U-Pb baddeleyite ages, and Hf, Nd isotope chemistry constraining repeated mafic magmatism in the Fennoscandian Shield from 1.6 to $0.9 \mathrm{Ga}$ : Contributions to Mineralogy and Petrology, v. 150, pp. 174-194.

Söderlund, U., Elming, S.-Å., Ernst, R.E. and Schissel, D., 2006, The Central Scandinavian Dolerite Group - Protracted hotspot activity or back-arc magmatism? Constraints from U-Pb baddeleyite geochronology and $\mathrm{Hf}$ isotopic data: Precambrian Research, v. 150, pp. 136-152.

Upton, B.G.J., Ramo, O.T., Heaman, L.M., Blichert-Toft, J., Kalsbeek, F., Barry, T.L. and Jepssen, H.F., 2005, The Mesoproterozoic Zig-Zag Dal basalts and associated intrusions of eastern North Greenland: mantle plume-lithosphere interaction: Contributions to Mineralogy and Petrology, v. 149 , pp. $40-56$.

Bernard Bingen graduated from the University of Brussels and works as senior geologist at the Geological Survey of Norway since 1997. He has developed his research in geochronology of orogenic processes, with regional expertise in the Sveconorwegian and Caledonian orogenic belts in Scandinavia. More recently, he was involved in reconnaissance geological mapping in Mozambique.
Jenny Andersson graduated from the University of Lund, and works as a senior geologist at the Geological Survey of Sweden since 2002. Her major research interest is to understand the links between metamorphic reactions and behaviour of isotopic systems of geochronometers in high-grade rocks. Previous work has focused on geochronology closely combined with field geology and petrology to characterise and directly date metamorphism and tectonic build up of the Sveconorwegian Province. She has also worked on metamorphic complexes in the Svecofennian Province and the subsurface Grenville Province of the Midwest, US.

Ulf Söderlund is a postdoctoral fellow at the GeoBiosphere Science Centre, Lund University, in Sweden. His research interest is dating of metamorphic and dynamic processes, and mafic rock suites in Fennoscandia and southern Africa. Part of Söderlund's current research focuses on time scale calibrations and determining new values of decay constants.

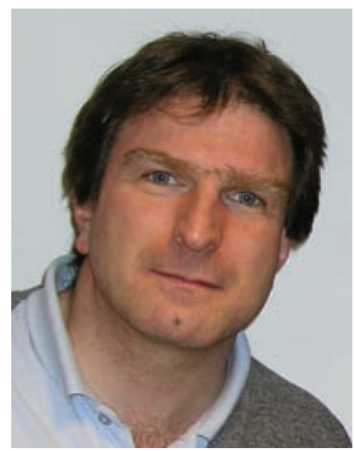

Charlotte Möller graduated from the University of Lund and works as a senior geologist at the Geological Survey of Sweden since 2003. Her main research interests are metamorphic petrology and its connections to structural geology, geochronology and tectonics. Her research has focussed on high-grade basement units in the Scandinavian Caledonides and the Sveconorwegian Province.
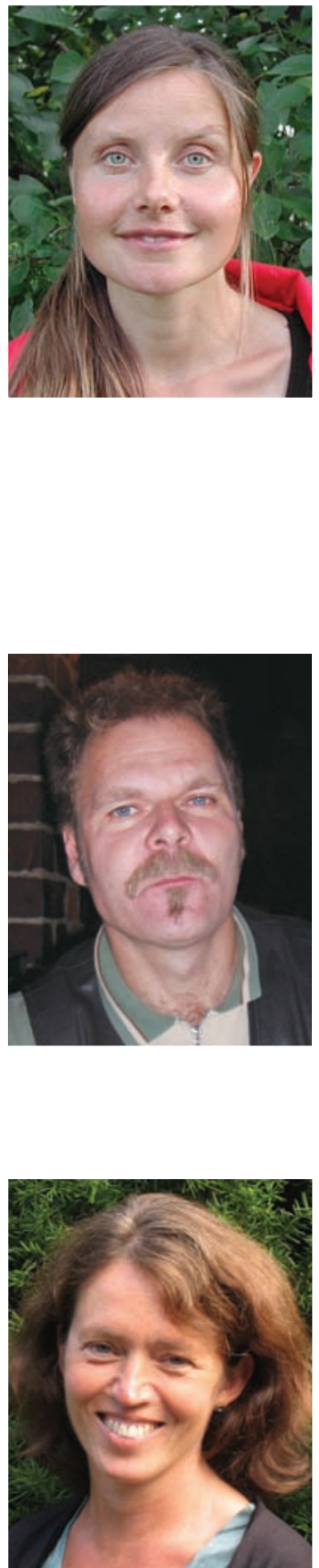